Сніцаренко П. М., д-р техн. наук, ст. наук. співроб. (0000-0002-6525-7064); Ткаченко В. А., канд. військ. наук (0000-0002-9625-2434); Сокуренко В. В.

Центр воєнно-стратегічних досліджень Національного університету оборони України імені Івана Черняхівського, Київ

\title{
Аналіз досвіду оборонних оглядів в Україні та провідних державах-членах НАТО для визначення перспектив розвитку Збройних Сил України
}

Резюме. У статті аналізується досвід оборонних оглядів в Україні, особливості організації та здійснення оборонного планування в державах-членах НАТО. За результатами цього аналізу авторами пропонується своє бачення підходів до визначення стратегічних цілей і пріоритетних напрямів розвитку Збройних Сил України на довгострокову перспективу.

Ключові слова: оборонний огляд; оборонне планування; НАТО; стратегічні цілі розвитку.

Постановка проблеми. У розвинених проблематика формування майбутнього обрису державах світу нормою військового будівництва і складовою цивільного контролю за процесами військових реформ є оборонний огляд, який не лише здійснює аналіз воєнної політики держави, a й окреслює відповідальність влади за визначення завдань та умов застосування збройних сил, їх чисельність, структуру та основи функціонування. Ефективне виконання комплексу заходів оборонного огляду дало змогу провідним державам-членам НАТО зробити значний крок у справі створення невеликих за чисельністю, сучасних і всебічно забезпечених збройних сил.

Зважаючи на ці світові тенденції, в Україні з перших років XXI століття також запроваджено практику проведення оборонних оглядів [1] та набуто відповідний досвід.

Практичний інтерес щодо вдосконалення процедури проведення оборонного огляду в Україні, відповідно до нової стратегії національної безпеки, викликає потребу урахування досвіду попередніх оборонних оглядів, досвіду держав-членів НАТО, зокрема, для пошуків підходів до визначення стратегічних цілей та пріоритетних напрямів розвитку Збройних Сил України (ЗС України) на довгострокову перспективу.

Метою статті є обгрунтування підходів до визначення стратегічних цілей та пріоритетних напрямів розвитку ЗС Україні на довгострокову перспективу на основі результатів аналізу досвіду оборонних оглядів в Україні та провідних державахчленах НАТО.

Аналіз останніх досліджень і публікацій показує, що на сьогодні активно досліджується ЗС України за досвідом держав-членів Альянсу. Вивченню процесу оборонного планування (ОП) у державах-членах НАТО присвячена значна кількість досліджень [2-6]. Проте недостатньо уваги приділялось питанням, які пов'язані 3 розвитком методу оборонного планування, що грунтується на спроможностях суб'єктів виконати завдання за призначенням. Зокрема, не враховувались певні відмінності, що пов'язані 3 особливостями оборонного планування на основі спроможностей (ОПОС) в окремих державах-членах НАТО і Альянсу загалом і можливостями адаптації системи ОП 3С України до аналогічних систем цих країн. Водночас, "механічне" копіювання способів ОП, притаманних окремим провідним державам Свропи та світу, і привнесення їх у систему ОП України, імовірно, не дасть змоги досягнути бажаного результату.

Отже, аналіз сучасних наукових публікацій в українському фаховому середовищі стосовно ОП в Україні показав, що на сьогодні відсутній дієвий методичний апарат визначення стратегічних цілей та пріоритетних напрямів розвитку 3С України на довгострокову перспективу, 3 урахуванням досвіду ОП у державах-членах НАТО.

Виклад основного матеріалу. Після розпаду СРСР 3С України успадкували модель радянської військової системи будівництва та розвитку, але вони потребували змін для відповідності до сучасних умов.

У 2003 році, вперше, було прийняте рішення про проведення оборонного огляду в ЗС України, інших військових формуваннях та розроблення документів ОП стратегічного 
рівня, що притаманно державам-членам НАТО [1]. Законодавством України визначено, що оборонний огляд - процедура оцінювання стану і готовності сил оборони до виконання завдань 3 оборони України, стану їх кадрового, фінансового, матеріально-технічного та інших видів забезпечення. За результатами оборонного огляду розробляється стратегічний оборонний бюлетень Украӥни - документ оборонного планування, що визначає основні напрями реалізації воєнної політики України, стратегічні цілі розвитку та очікувані результати їх досягнення 3 урахуванням актуальних воєнно-політичних загроз і викликів [7].

У 2004 році Указом Президента України за результатами огляду був ухвалений перший Стратегічний оборонний бюлетень України [8]. У документі було визначено: перелік завдань щодо захисту суверенітету та територіальної цілісності України; терміни підготовки сил; завдання стосовно реформування системи управління ЗС України, модернізації та закупівлі нових зразків озброєння і військової техніки (ОВТ) та розв'язання проблем соціального захисту військовослужбовців i членів їх сімей.

Оборонний огляд 2004 року став першим досвідом держави щодо розроблення оборонної стратегії за принципами, прийнятими у провідних державах світу. Його результати та висновки дали змогу розпочати системну трансформацію ЗС України в 2005 2008 роках. Стратегічний оборонний бюлетень України на період до 2015 року став основою для середньострокового ОП та окреслив основні позиції політики України в оборонній сфері на довгострокову перспективу. Бюлетень був документом, на який опиралися під час розроблення Державної програми розвитку Збройних Сил України на 2006 - 2011 роки.

Проте не всі результати огляду були впроваджені, реалізації заходів завадила низка об’єктивних обставин. Зокрема, для планування реформування 3С України економічні показники розвитку держави, що прогнозувалися, виявилися далекими від реальних, бюджетні видатки були значно нижчі від запланованих. Це призвело до того, що практичні реформи розгорнути повною мірою не вдалося, а деякі були виконані лише частково. За період $2006-$ 2011 років Державна програма була профінансована лише на $75,6 \%$ від потреб. Виявилося, що за час виконання програми якісні показники ЗС України все більше відставали від змін у сфері оборони, обумовлених швидким розвитком інформаційних технологій. $\mathrm{He}$ вдалося повною мірою оснастити українське військо сучасним ОВТ, не вистачало коштів на утримання військовослужбовців військової служби за контрактом та на розв'язання їх соціальних проблем, насамперед, житлових.

За 4 роки після проведення першого оборонного огляду ситуація в Україні зазнала змін як у політичному, так i економічному плані. Через світову економічну кризу бюджет країни зменшився, відбулися зміни як у внутрішній, так i у зовнішній політиці держави.

Така ситуація потребувала перегляду державної воєнної політики для збереження механізмів воєнної безпеки.

У червні 2008 року набуло чинності рішення Ради національної безпеки і оборони України щодо проведення наступного оборонного огляду (липень 2008 року грудень 2012 року) [9].

У листопаді 2008 року організаційний етап оборонного огляду було завершено, а вже у січні 2009 року 3 метою доведення результатів першої частини огляду була проведена міжвідомча науково-практична конференція. Було визначено першочергові завдання та надано повноваження Експертній комісії МО України щодо розроблення Стратегічного оборонного бюлетеня. Комісія отримала право залучати до розгляду та створення документа як представників інших гілок влади, так і представників громадських організацій.

Згідно $з$ опрацьованими матеріалами був розроблений відповідний план. Але складнощі в економіці держави не давали змоги спрогнозувати основні економічні показники, на яких мав би грунтуватися план. Нестабільність економічної системи країни стала основним викликом під час виконання огляду.

Під час оборонного огляду було вперше розглянуто стан вітчизняного обороннопромислового комплексу (ОПК). За роки незалежності, незважаючи на окремі успіхи в експортній сфері, він розвивався незадовільно, в основному через брак коштів для закупівлі OBT для потреб ЗС України. Аналітичною групою були визначені основні напрями військово-технічної політики, але без реальних економічних показників на перспективу ці рекомендації залишилися лише на папері.

За результатами огляду було виявлено значні складнощі у системі управління країною та військами на особливий період, насамперед, через такі причини: 
недосконалість правового регулювання відносин вищого керівництва держави та інших суб'єктів воєнної організації;

відсутність єдиної функціональної системи безпеки та оборони;

відсутність розподілу функцій між гілками влади, низький рівень їх взаємодії, складність прийняття швидких рішень;

зміна акценту 3 класичних способів відбиття збройної агресії до політики попередження конфлікту [2].

Слід зазначити, що хід огляду припав на час загострення політичної та економічної кризи в Україні. Перше завадило точніше визначити напрями інтеграції у зв'язку 3 президентськими виборами в Україні, де кандидати виголошували різні напрями подальшого руху країни. Мінекономіки та Мінфін не змогли визначити чіткі рамки прогнозованих економічних показників. Усе це відсунуло кінцеві терміни оборонного огляду та знизило його результативність.

Переломним роком для України став 2014 рік, коли стала очевидна необхідність глибоких реформ в ЗС України та потреба докорінних змін в основних нормативноправових документах, що регулюють діяльність державних інституцій щодо збройного захисту України [3].

У квітні 2014 року 3 огляду на необхідність реалізації комплексу завдань щодо нейтралізації нагальних тоді загроз національній безпеці України та для забезпечення ефективного використання наявних ресурсів Рада національної безпеки i оборони України прийняла рішення [10], яким передбачалось Кабінету Міністрів України організувати у місячний строк проведення комплексного огляду сектору безпеки і оборони Украӥни 3 використанням можливостей Спільної робочої групи Україна-НАТО 3 питань воєнної реформи високого рівня.

Хронологія подій минулого періоду дала підставу вважати, що оборонний огляд 2014 2015 pp. був недостатньо організованим, починаючи 3 некоректності постановки завдань (організувати у місячний строк проведення комплексного огляду сектору безпеки i оборони України - нереально) та відсутності дієвого контролю за цим процесом, оскільки керівного органу 3 відповідними повноваженнями, який міг би реально координувати й контролювати зусилля органів влади та управляти цим процесом в структурі державного управління, не було.

Саме неготовністю системи державного управління керувати цим процесом військові науковці пояснюють невизначеністю оборонного будівництва та проведення комплексного огляду сектору безпеки i оборони України у 2014-2015 pp.

До невизначеностей, що розглядались тоді як негативні, вони віднесли розбалансованість військового управління, недосконалість системи ОП, брак належного наукового рівня обгрунтованості прийнятих тоді рішень, нераціональне використання бюджетних коштів, неналежну взаємодію та координацію дій органів державної влади та сил оборони [11].

$\begin{array}{ccc}\text { Аналіз оборонних оглядів } & \text { у провідних } \\ \text { державах-членах НАTO. } & \text { у провідних }\end{array}$
державах-членах НАТО стратегічний оборонний огляд став засобом оцінювання сучасного стану їх оборонного потенціалу та визначення шляхів досягнення його необхідного рівня в оптимальний спосіб у майбутньому.

НАТО на сьогодні $€$ найбільшою військовою міжнародною організацією, яка декларує забезпечення безпеки кожної держави, що входить до неї.

Забезпечення безпеки базується на принципах, основними з яких є [14]:

стандартизація та оперативна взаємосумісність збройних сил держав Альянсу;

оптимізація організаційно-штатної структури, бойового та чисельного складу відповідно до умов ведення сучасних війн $\mathrm{i}$ збройних конфліктів;

прозорість військового бюджету державучасниць тощо.

Реалізація цих принципів забезпечується, зокрема, й розвинутою системою ОПОС, яка утворена в Альянсі.

Оборонне планування на основі спроможностей передбачає створення, розвиток і підтримання оптимального складу необхідних спроможностей у межах наявних ресурсів. Ефективними шляхами нарощування спроможностей може бути удосконалення доктрин, основ застосування військ (сил), структур органів управління та військових частин, впровадження нових форм і способів ведення операцій і бойових дій, поліпшення системи відбору, навчання, підготовки та мотивації персоналу тощо.

На відміну від планування на основі загроз, оборонне планування на основі спроможностей полягає в зосередженні зусиль не на створенні нових організаційних структур для забезпечення переваги відповідному бойовому потенціалу противника, a на 
розвитку спроможностей військ (сил) для ефективного виконання визначених завдань.

Процес ОПОС у НАТО включає п'ять основних етапів, які мають, як правило, послідовний та циклічний характер [4]: визначення засад державної політики у сфері безпеки i оборони; визначення необхідних спроможностей військ (сил) для виконання завдань; розподіл спроможностей та визначення завдань; імплементація; оцінка результатів.

За результатами оцінки готується Огляд спроможностей та Доповідь про спроможності.

Процес ОПОС застосовується під час проведення планування розвитку сил і засобів (спроможностей) на середньострокову та довгострокову перспективи.

Системи планування, програмування, бюджетування, виконання, які покладені в основу ОПОС держав-членів блоку, взаємопов'язані одна 3 одною зворотними зв'язками: довгострокове планування реалізується середньостроковими програмами, основним джерелом виконання яких $\epsilon$ бюджетні асигнування [5]. Зміни запланованих ресурсів автоматично викликають перегляд середньострокових програм, які, зі свого боку, потрубують перегляду довгострокових планів. Зворотній зв'язок визначає коригування попереднього процесу.

Слід зазначити, що НАТО $є$ міжнародною організацією, держави-члени якої виділяють ресурси, необхідні для забезпечення iï діяльності. До того ж переважна більшість збройних сил і ресурсів держав-членів НАТО залишається під командуванням і контролем власних держав.

Таким чином, особливістю ОПОС НАТО $€$ те, що:

Стратегічною концепцією оборони $\mathrm{i}$ безпеки членів НАТО кожній державі визначаються національні спроможності, які необхідні для досягнення цілей Альянсу;

єдиного стандарту для ОП у державахчленах НАТО не існує;

кожна держава Альянсу має свою систему ОПОС, на основний зміст організації та здійснення якого впливають характерні риси економічного устрою, прийнята в державі системи прогнозування та планування іiі розвитку, умови, в яких здійснюється планування, національні традиції тощо;

основою для узгодженості результатів ОП є Угода про стандарти НАТО;

середньострокове ОП, зазвичай, орієнтоване на строк обрання уряду; огляди оборонних спроможностей у державах-членах НАТО проводяться кожні два роки.

3 огляду на це, кожна держава-член НАТО, враховуючи загальні цілі та завдання Альянсу, самостійно визначає стратегічні цілі та напрями розвитку власних збройних сил.

Найбільшого розвитку процес оборонного планування отримав у Сполучених итатах Америки. Кодексом Законів США встановлено, що міністр оборони має раз на чотири роки проводити впродовж року, наступного за цим періодом, всебічний аналіз, відомий як “чотирирічний оборонний огляд" (ЧОО) стратегії національної оборони, структури збройних сил, планів модернізації збройних сил, інфраструктури, бюджетного плану та інших елементів оборонної політики Сполучених Штатів на найближчі 20 років [12].

Основними цілями оборонного огляду у США $€$ :

розроблення стратегії національної оборони відповідно до останньої затвердженої президентом США стратегії національної безпеки;

визначення структури сил, інфраструктури, інших елементів, необхідних для успішного виконання завдань, передбачених стратегією національної оборони;

створення бюджетного плану та визначення ресурсів для виконання всього спектра завдань при рівнях ризиків від низького до помірного.

Основою для проведення ЧОО $\epsilon$ забезпечення реалізації завдань стратегії національної безпеки, яка, відповідно до Закону США про національну безпеку, публікується у вигляді щорічної доповіді президента Конгресові одночасно 3 поданням бюджету [13].

Міністр оборони протягом року, наступного за роком, у якому проводиться огляд, але не пізніше дати, на яку президент США подає до Конгресу бюджет на наступний фінансовий рік, представляє до комітетів 3 питань збройних сил Сенату i Палати представників доповідь із ЧОО. Перелік питань, які включаються в доповідь, визначений на законодавчому рівні й охоплює в основному такі питання (розділи) [12]:

результати огляду, зокрема, всебічне обгрунтування стратегії національної оборони Сполучених Штатів (для низького та помірного рівнів ризиків);

інтереси національної безпеки США; 
загрози інтересам національної безпеки США, а також сценарії їх реалізації;

стан готовності сил США; співпраця із союзниками; час приведення сил у бойову готовність; рівень участі в операціях; інтенсивність, тривалість та наслідки конфліктів;

структура сил та боєготовність для ведення бойових дій, їх можливості, співвідношення бойових сил і сил підтримки;

персонал і політика підтримки, необхідні для участі в конфліктах на строк понад 120 днів;

завдання резервних компонентів, сили, можливості й озброєння;

можливості транспортних повітряних, морських і наземних перевезень;

заходи зі стримування та адекватного воєнного реагування на очікувані конфлікти, розподіл ресурсів у разі виникнення конфліктів;

оборона держави та реалізація цілей цивільної оборони активними й резервними компонентами;

будь-які інші питання, які міністр оборони вважає за доцільне.

Після завершення кожного ЧОО військове командування готує й подає міністрові оборони свої оцінки цього документа, зокрема оцінки ризиків. Такі оцінки разом 3 відповідними коментарями обов'язково включаються в доповідь міністра оборони у повному обсязі.

Крім того, законодавчо встановлена обов'язковість проведення незалежної оиінки ЧОО. Для цього міністр оборони створює групу з відповідних фахівців, яка представляє свої оцінки ЧОО, рекомендації та пропозиції.

Законодавство визначає також проведення раз на чотири роки в рамках ЧОО огляду якості життя військовослужбовиів.

До них включаються матеріали вивчення морального стану, соціального забезпечення й відпочинку військовослужбовців. Визначаються заходи, потрібні для забезпечення військовослужбовців якісними умовами життя, для стимулювання успішного виконання ними встановлених завдань.

Оцінюючи умови, у яких опинилися США, визначається оборонна стратегія та новий склад збройних сил, розглядається перехід до нових технологій війн. У ЧОО визначаються також основні параметри структурних елементів збройних сил за встановленими критеріями, які мають бути відображені в перспективній Оборонній програмі.
Таким чином, ЧОО США спрямований на коригування стратегії національної оборони та оборонної програми на майбутні роки відповідно до завдань стратегії національної безпеки. Активну участь у його обговоренні бере законодавча гілка влади. Його терміни узгоджені з термінами планування оборонного бюджету, а ресурсне забезпечення реалізації завдань національної оборони - 3 реальними економічними можливостями держави.

Удосконалення системи оборонного планування в Україні в напрямку переходу на планування на основі спроможностей та наближення його до прийнятих у НАТО стандартів для ЗС України є завданнями на найближчу перспективу, що визначено в Концепції розвитку сектору безпеки і оборони України та Стратегії національної безпеки України $[15,16]$.

Координацію у сферах національної безпеки i оборони України здійснює Рада національної безпеки i оборони України відповідно до статті 107 Конституції України та Закону України "Про Раду національної безпеки і оборони України".

Рада національної безпеки і оборони України 3 урахуванням змін у безпековому середовищі визначає концептуальні підходи, напрями, заходи із забезпечення національної безпеки і оборони, схвалює проєкти стратегій, концепцій, державних програм та інших стратегічних документів, якими визначаються основні напрями i завдання державної політики у сферах національної безпеки $\mathrm{i}$ оборони, здійснює координацію і контроль за їх виконанням [7].

Важливим підгрунтям забезпечення планування у сфері оборони $є$ визначення стратегічних цілей та пріоритетних напрямів розвитку ЗС України на довгострокову перспективу.

Від правильності вибору стратегічних цілей i пріоритетних напрямів розвитку ЗС України залежить успіх у підготовці до захисту суверенітету (оборони) держави.

На наш погляд, стратегічна иіль це бажаний стан об'єкта планування або бажаний досягнутий кінцевий результат довготривалої діяльності, а пріоритетний напрям розвитку сукупність визначених цілей та завдань розвитку, послідовна поступова реалізація яких дає змогу оптимально рухатися до досягнення головної (кінцевої) мети. Формування стратегічних цілей можна розглядати як встановлення параметрів очікуваного стану об’єкта планування на визначений кінцевий момент часу 
(довготривалий проміжок часу) у процесі його розвитку з урахуванням динаміки зовнішнього середовища та ресурсного забезпечення.

Безумовно, на процес визначення стратегічних цілей та пріоритетних напрямів розвитку 3С України на довгострокову перспективу впливає безпекове середовище навколо України, стан 3С України, можливості держави щодо ресурсного забезпечення.

Безпекове середовище - сукупність зовнішніх і внутрішніх відносин між суб'єктами в усіх сферах національної безпеки, а також умов, факторів і обставин, які певним чином впливають або можуть впливати на ці відносини [17].

Одним з основних завдань, яке має бути розглянуто під час оборонного огляду, є аналіз безпекового середовища за межами країни, а також тенденції його розвитку на довгострокову перспективу.

Саме навколишнє безпекове середовище визначає потребу держави у збройних силах (ï чисельність) і воно впливає на їх будівництво та розвиток.

Оцінювання стану та перспектив розвитку безпекового середовища передбачає [17]:

опис безпекового середовища (глобальні, регіональні та національні аспекти) у контексті воєнної безпеки;

оцінювання стану та прогнозування розвитку воєнно-політичної та воєнностратегічної обстановки, реальних потенційних викликів та загроз у воєнній сфері;

розроблення імовірних сценаріїв виникнення ситуацій воєнного характеру із застосуванням сил оборони до виконання завдань із захисту держави 3 розподілом відповідальності між їх складовими.

Розвиток безпекового середовища відбувається внаслідок зміни:

інтересів і суперечностей глобального та регіонального масштабу;

ресурсів (людських, економічних і природних);

складу i характеру дій сил щодо реалізації інтересів, зокрема пріоритетів розвитку складових могутності (технологій, кількісно-якісних параметрів озброєнь тощо), доктринальних установок;

характерних рис сучасних воєнних конфліктів.

Під час опису безпекового середовища передбачається опрацювання таких питань:

аналіз концептуальних документів (концепцій, доктрин, стратегій тощо), а також аналітичних праць провідних іноземних i вітчизняних експертів щодо зовнішньої та внутрішньої політики в усіх сферах, які можуть впливати на застосування воєнної сили, для виявлення інтересів та мотивації сил; оцінювання та прогнозування складових воєнної могутності протилежних сил (воєнного, економічного, науково-технічного i духовного потенціалів) та готовності до застосування воєнної сили для реалізації своїх інтересів;

оцінювання та прогнозування суперечностей між силами за проблемами відносин у світовому масштабі з проекцією на регіон довкола України;

оцінювання та прогнозування ризиків як результату розвитку безпекового середовища, які можуть реалізуватись на воєннополітичному горизонті понад п'ять років i призвести до негативних наслідків для безпеки України;

формування сценаріїв воєннополітичних ситуацій, які потенційно можуть вимагати застосування (залучення) сил оборони, а також характер участі складових сил оборони у зазначених сценаріях.

Стратегічні цілі та завдання оборонної сфери на перспективу, мають визначатися на основі аналізу потенційних загроз і викликів та розроблених сценаріїв, які б могли реально статися. На основі аналізу кожної імовірної ситуації має бути сформовані вимоги до ЗС України, які б відповідали визначеному сценарію 3 урахуванням ризиків, які можна вважати прийнятними. Для кожної ситуації має розраховуватися кількість ресурсів для вирішення завдань, організаційні можливості оборонної сфери та визначатися вимоги до структур, які б мали бути задіяні у разі реалізації кризового сценарію. Особливу увагу слід приділяти заходам, які б дали змогу уникнути конфлікту.

Можливі сценарї воєнно-політичних cumуацій, що потребують застосування (залучення) сил i засобів сектору безпеки i оборони - прогнозована сукупність намірів i дій сил (суб'єктів), а також умов, факторів і обставин, яка для реалізації національних інтересів України потребуватиме реагування із застосуванням (залученням) сил оборони.

Отже, під час опрацювання різних сценаріїв мають визначатися спроможності та структури, які передусім найважливіші в оборонному плані.

Під час визначення стратегічних цілей i пріоритетних напрямів розвитку 3С України на довгострокову перспективу можуть застосовуватися наукові методи та інструменти стратегічного аналізу. 
Метод експертних оцінок Дельфі (Delphi technique) - досконаліший метод колективної оцінки. Він передбачає заміну прямих колективних обговорень програмою індивідуальних опитувань, які здебільшого проводять у формі таблиць експертної оцінки. Відповіді експертів узагальнюють і повертають їм назад, після чого експерти уточнюють свої відповіді. Таку процедуру повторюють кілька разів, поки не досягають прийнятної збіжності всіх висловлених думок.

Методика комплексного аналізування (PEST-analysis) - це інструмент, призначений для виявлення політичних (P - political), економічних (E-economic), соціальних $(\mathrm{S}-$ social $) \quad \mathrm{i}$ технологічних ( $\mathrm{T}-$ technological) аспектів середовища, які впливають на об'єкт. Результати PEST-аналізу оформляються у вигляді матриці та дають змогу всебічно оцінити ситуацію.

Методика аналізування сильних і слабких сторін, можливостей та загроз (SWOT-analysis). SWOT-аналіз застосовується у процесі стратегічного планування, що полягає в розділенні чинників і явищ на чотири категорії: сильних (Strengths), і слабких (Weaknesses) сторін будь-якого проєкту, можливостей (Opportunities), що відкриваються під час його реалізації, та загроз (Threats), пов'язаних з його здійсненням.

Методика аналізування прогалин (Gap Analysis). Gap-аналіз - метод аналізу інформації, який вивчає розбіжність між бажаним (чого потрібно досягти) i реальним (чого фактично можна досягти). GAP-аналіз - це висвітлення проблем між бажаною і реальною дійсністю об’ єкта, процесу.

Методика профілювання ризиків (Risk Projiling) - це сукупність процедур і методів обробки інформації для визначення наявних та потенційних ризиків (можливості настання загрози у сфері діяльності) 3 використанням індикаторів ризику (ознак чи сукупності ознак із заданими параметрами, використання яких дає змогу здійснювати вибір об'єкта, що становить ризик) для розроблення профілю ризику (документ, що відображає сукупність інформації про загрозу ризику та визначає порядок дій у разі їх виявлення).

Кінцевим узагальненим результатом досягнення стратегічних цілей розвитку $3 \mathrm{C}$ України на довгострокову перспективу має бути перспективна модель Збройних Сил, укомплектованих підготовленим особовим складом, оснащених сучасними системами управління, озброєнням та військовою технікою, запасами матеріальних засобів, які будуть спроможні виконати весь комплекс завдань щодо захисту суверенітету (оборони) держави.

Перспективна модель Збройних Сил інтегрована сукупність кількісних $\mathrm{i}$ якісних показників (параметрів), які загалом відображають спроможність Збройних Сил до виконання завдань за призначенням.

\section{Висновки:}

1. Досвід проведених оборонних оглядів в Україні свідчить, що для успішного досягнення якісних кінцевих результатів необхідно застосування науково-методичного підходу щодо:

ретельного планування заходів оборонного огляду;

забезпечення підготовки особового складу (персоналу), який безпосередньо виконуватиме заходи оборонного огляду;

здійснення відбору особового складу (персоналу) та формування аналітичних груп для узагальнення результатів оборонного огляду із застосуванням наведених вище методів та інструментів стратегічного аналізу;

забезпечення єдиного керівництва проведенням оборонного огляду.

2. Основними критеріями оборонних оглядів в Україні мають бути: реалістичність (опора на можливості як матеріальні, так i організаційні), раціональність (за критерієм вартість-ефективність) та прозорість (суспільство, платники податків мають чітко розуміти та контролювати куди витрачаються бюджетні кошти).

3. Урахування позитивної практики США та інших держав-членів НАТО під час проведення вітчизняного оборонного огляду та Стратегічного оборонного бюлетеня дасть змогу підвищити якість заходів оборонного планування, створити ефективний механізм взаємодії всіх ланок державної влади у сфері підтримання обороноздатності держави, забезпечити формування реальних цілей на всіх рівнях оборонного планування, що гарантує їх досягнення необхідними бюджетними коштами.

4. Науково-методичні та окремі практичні підходи й досвід проведення оборонних оглядів у Міністерстві оборони та Збройних Силах України, що наведені у наукових працях військових фахівців та науковців, потребують певного перегляду та подальшого розвитку 3 урахуванням позитивного досвіду держав-членів HATO.

Перспектива подальших досліджень полягає в потребі розроблення грунтовних наукових методів, методик, моделей, програм (алгоритмів) визначення основних керівних чинників оборонного планування, зокрема, конкретизації стратегічних цілей та пріоритетних напрямів розвитку $3 \mathrm{C}$ України на довгострокову перспективу, перспективного складу та структури Збройних Сил, моделі органів управління Збройними Силами (силами оборони).

\section{СПИСОК ВИКОРИСТАНОЇ ЛІТЕРАТУРИ}


1. Про проведення оборонного огляду : Указ Президента України від 4 липня 2003 року № 565.

2. Корендович В. С. Другий оборонний огляд в Україні. Його попередні результати та виклики. Оборонний вісник. Вип. № 2/2010.

3. Оборонний огляд: український вимір 2014-2018 : монографія / Ф. Саганюк, А. Павліковський, П. Щипанський, В. Павленко та ін. ; за заг. ред. д. військ. н., проф. І. Руснака. Київ : MO та ГШ ЗС України, НУОУ, 2019. 196 с.

4. Дєнєжкін М. М., Наливайко А. Д., Поляєв А. I. Особливості оборонного планування у державах-членах НАТО на основі спроможностей. 3б. наук. пр. ЦНДІ ЗСУ. Київ, 2017. № 3 (77).

5. Дєнежкін М. М., Плахута О. Л. Стандарти НАТО та оборонне планування в Збройних Силах України. $3 б$. наук. пр. ЦНДІ ЗСУ. Київ, 2016. № 3 (77).

6. Затинайко О. I., Потапов Г. М. Деякі проблеми вдосконалення функціонування сектору безпеки i оборони України за результатами оборонного огляду. Наука і оборона. 2012. № 3.

7. Про національну безпеку України : Закон України від 21 червня 2018 року № 2469-VIII.

8. Указ Президента України Про рішення Ради національної безпеки і оборони України від 17 червня 2004 року "Про Стратегічний оборонний бюлетень України на період до 2015 року” від 22 червня 2004 року № 670 .

9. Указ Президента України Про рішення Ради національної безпеки і оборони України від 30 травня 2008 року “Про проведення оборонного огляду” від 27 червня 2008 року № 598.

\section{Стаття надійшла до редакційної колегії 19.08.2019}

Сницаренко П. Н., д-р техн. наук, ст. науч. сотр.;

Ткаченко В. А., канд. воен. наук;

Сокуренко В. В.;

Зубков В. П.

Центр военно-стратегических исследований Национального университета обороны Украины имени Ивана Черняховского, Киев

Анализ опыта оборонных обзоров в Украине и ведущих государствах-членах НАТО для определения перспектив развития Вооруженных Сил Украины

Резюме. В статье анализируется опыт оборонных обзоров в Украине, особенности организации и осуществления оборонного планирования в государствах-членах НАТО. По результатам анализа авторами предлагается свое видение подходов к определению стратегических целей и приоритетных направлений развития Вооруженных Сил Украины на долгосрочную перспективу.

Ключевые слова: оборонный обзор; оборонное планирование; НАТО; стратегические цели развития.

P. Snyzarenko, DsT (Technical), senior researcher;

V. Tkachenko, PhD (Military);

V. Sokurenko;

V. Zubkov

Center for Military and Strategic Studies of the National Defence University of Ukraine named after Ivan Cherniakhovskyi, Kyiv

An analysis of the experience of defense reviews in Ukraine and leading NATO member states to determine the prospects for the development of the Armed Forces of Ukraine

Resume. The article analyzes the experience of defense reviews in Ukraine, the peculiarities of organization and implementation of defense planning in NATO member states. Based on the results of this analysis, the authors propose their vision of approaches to the definition of strategic goals and priority directions of the development of the Armed Forces of Ukraine for the long-term perspective.

Keywords: defense planning; defense review; NATO; strategic development goals. 